\title{
Deconstruction of the Construction: Derridean Study of Selected Shakespeare's Comedies
}

\author{
1, *Seyyedeh Zahra Nozen; ${ }^{2}$ Pegah Sheikhalipour \\ ${ }^{1}$ Amin Police University, Tehran, Iran; ${ }^{2}$ Malayer University, Hamadan, Iran. \\ *Corresponding author: nozenzahra@gmail.com
}

\begin{abstract}
Since it was first introduced by Jacques Derrida in the late 1960s, deconstruction, as a method of reading, has been applied to literary texts by critics to reveal the hidden messages of texts and provide opportunities to rethink textual and cultural norms and conventions. While the western tradition has always prioritized tragedy over comedy due to its elegance and graveness, this research tends to focus on comedy as an entity in itself. Tragedy, especially in the Shakespearean sense of the word, has been considered by critics as a "construction" which is well-wrought and perfect in nature. Comedy, on the other hand, is notable for the laughing at the laughable and mocking the unfit. Put differently, there has always been a latent, freewheeling "deconstruction" within comedy, especially the Shakespearean. There is, thus, an attempt here to prove, on the one hand, how comedy can be put forth not as an inferior genre but as a supplement to tragedy and, on the other, how comedy moves toward deconstruction and how it tends to subvert or deconstruct the constructions. Investigating a selection of Shakespeare's comedies including As You Like It, The Merchant of Venice, and Twelfth Night, this study compares and contrasts Shakespearean comedy in light of some Derridean concepts. Along with it, Shakespearean ideas and concepts which are interconnected with those of Derrida are introduced and are buttressed through some meticulously chosen excerpts. Bearing in mind that Derrida is in a habit of deconstructing the so-called established creeds, Shakespeare's texts are exposed to a deconstructive reading to examine how deceptively simple ideas are dealt with in his selected comedies. Also, as numerous enigmas have for years revolved around the personality of William Shakespeare, this study also aims to take up certain critical idioms of the Derridean canon, elaborate on them and then relate them to the selected plays from Shakespearean oeuvre in order to disclose some personal aspects of Shakespeare's personality as a historical figure.
\end{abstract}

Keywords: Shakespeare, Comedy, As You Like It, Twelfth Night, The Merchant of Venice, Derrida, Deconstruction. 


\section{Introduction}

One of the popular methods of criticism in general is deconstruction which is usually associated with the name of the great French Philosopher Jacques Derrida. Some people believe that it is a misunderstanding to attribute everything in deconstruction to Derrida, for deconstruction is such a vast school of thought, philosophy, and critical trajectory that cannot be put under a single umbrella term or only a person's name such as Derrida's. However, no one could deny the salient role of Derrida in the development of deconstruction. Deconstruction can be viewed from two different perspectives. One involves retaining a broad version of deconstruction which is quite popular too. The other draws on a narrower version of deconstruction which seems to be more technical. In fact, the more technical version involves a group of methods and techniques that can allow us to read different types of texts. Such reading methods and techniques are actually connected to special perspectives on the nature of meaning and language. Because of the fact that deconstruction has been a popular school of thought and criticism, many would consider it as a strategy of criticism strategy or a different approach in reading.

In the United States of America, deconstruction grew into a popular criticism strategy at different universities and institutes. That is why it was misunderstood by many people as a synonym for reader response theory which claims that a reader can produce the meaning of a text through having constant encounter with it. In Europe, the story was a little bit different with deconstruction being usually considered as the opposite extreme of structuralism, leading to deconstruction being called a poststructuralist approach. In structuralism, it is usually argued that linguistic structures can form the thoughts of individuals. Thus, the concept of cultural meaning did not receive any attention. Deconstruction is against the idea that meaning is stable and universal.

Regarding the idea that deconstruction is not a method, Derrida tried a lot to argue that it should be considered as an activity of reading. One of the most commonly used deconstructive arguments is based on oppositions. For example, Derrida (1976) argues that writing and speech can be considered as two opposite concepts. Regarding this type of analysis, the concept of "privilege" plays a crucial role. Actually, through a deconstructive lens, we can analyze how a concept is "privileged" over others by referring to its value, importance and universality in comparison to the opposite. As different things may have a lot of different opposites, one can argue that different sorts of "privilege" are available. One of the most important applications of deconstruction is for ideological critique; to destabilize ideologies. Actually, deconstruction can be practical in this regard as ideologies surpass and privilege specific characteristics of social life in the opposites. In 
deconstruction, an attempt is usually made to find the deemphasized or surpassed things (Unger, 1986; Frug, 1984; Dalton, 1985; Peller, 1985; Balkin, 1987).

They are in interaction with the arguments in the text and how they can challenge them. When a deconstructive analysis is done, usually the researcher tries to find the unexpected or the unusual relationship which may exist in different parts of the text. Sometimes, the things that seem to be trivial or unusual for readers in a text might be very important as far as deconstructive analysis is concerned. Upon having deconstructive analyses, various meanings of concepts and key terms in a text as well as their relationships assume importance (Balkin, 1990b; Balkin, 1989).

It is not true to think that deconstruction tries to prove all texts are meaningless; rather, it is argued that there are multiple, different, and sometimes contradictory meanings in a single text all at the same time, none of them being superior to the other. Regarding the boundaries in a text, it should be mentioned that deconstruction does not claim that there are no boundaries in texts; however, it tries to show how such boundaries can change if the context of evaluation or judgment changes. Instead of destroying the available oppositions in the concepts of a text, deconstruction shows new horizons as to the interpretation of such conceptual oppositions as a form of nested opposition (Balkin, 1990a) which is an opposition that includes two terms with similar dependence and difference. In fact, deconstruction tries to see how such similarity or difference is suppressed or overlooked. Thus, it places the emphasis on the significant role of (con)text in interpretation and judgment and the potentiality of meanings being changed in the light of the differences in the nature of contexts.

Going by the knowledge that there have been outstanding academic works employing Derridean reading to shed light on Shakespeare's plays, the present study has selected three ones that have not been subjected to such comprehensive reading and analysis before. Moreover, these three comedies offer another dimension to Shakespearean scholarship that is different from that of tragedies in terms of Derridean reading. One can see in these three plays that Shakespeare has inclined towards rather marginalized or even insignificant matters and personalities, people getting entangled in trivial matters and situations rather tainted with mockery and ridicule. These probably provide contextual opportunities for a Derrida-oriented mentality to observe the language plays, challenging the self-proclaimed centers of structures; centers such as religiosity, nobility, royalty, court manners, and so forth. More importantly, in these plays we see how the notion of self-built Renaissance Man (or in case of The Merchant of Venice, woman) could be understood in a much better way with Derridean insights taken into account. 
In addition, there are, more often than not, sharp oppositions between concepts, people, traditions and even institutions. These seemingly inconsolable oppositions are formed around the traditional metaphysics of presence and the platonic view that concepts such as presence and speech are superior to notions of absence and writing, respectively, with the former definitely preferred over the latter. These three plays provide a great opportunity for the reader of Derridean interests to witness how Shakespeare challenges rigid notions of identity, presence, speech, Christianity, so forth, with such great liberality that shakes their traditionally firm foundations. Despite all of the charm and excitement that these Derridean terms may offer, a scholar of Shakespeare must notice that finding these Derridean elements in a given text is not academically sufficient by itself. One must develop a line of argument which connects the consequences of applying Derridean terms to the flow of the texts regarding their lines, characters, contexts, and stories. The previously mentioned examples, though broad and general for the sake of brevity, will provide a proper bedrock on which such argument could be built and developed.

This paper embraces two fundamental terms in relation to two seminal genres of drama, i.e. tragedy and comedy. While the western tradition has always prioritized tragedy over comedy due to its elegance and graveness, this research tends to focus on comedy as an entity in itself. Tragedy starts with construction and ends with destruction. Comedy, on the other hand, opens with destruction and ends with construction. Hence the aim here is to prove, on the one hand, how comedy can be considered not as an inferior genre but as a supplement to tragedy.

As Frye (1964) observes, a critic's job is to take up an approach, Derridean deconstruction being a case in point, and read work(s) of literature through that lens to arrive at a new insight into the texts of a certain author. These unprecedented insights and new interpretations must be interwoven into the body of the previously conducted scholarly works on the texts under scrutiny in a given study. In the case at hand, the aim is to take up certain critical idioms of the Derridean canon, elaborate on them and then relate them to the selected plays from Shakespearean oeuvre.

Indeed, since Derridean and deconstruction forms of reading literary masterpieces have been and are still very popular among the academia, taking up this mantle in approaching a canonical author is surely not a new endeavor. However, the vastness of Derridean philosophy and Shakespearean canon allows one to always find new insights and interpretations and venture to reveal them. Thus, as Frye asserts "the central activity of criticism, which is the understanding of literature, is essentially one of establishing a context for the works of literature being studied" (1964: p.12); these new interpretations will help the readers of Shakespeare's plays understand his texts with more pleasure and deeper evaluation. Derrida has been used as an end in 
itself; the researchers try to use Derrida's approach as a means to another end, that is, to penetrate into Shakespeare's personalities through his comedies.

The Derridean terms and texts chosen to be considered and analyzed have not been used previously in Shakespearean scholarship in the manner of the present study. It is hoped that introducing these critical terms to the field of Shakespearean scholarship will reveal more of the greatness and depth of his plays and other texts. The outcome of this study will also relate to the structure of literature on a larger scale. This, according to Frye, is the ultimate triumph of any proper work of literary criticism: "This means relating them to other things: to their context in the writer's life, in the writer's time, in the history of literature, and above all in the total structure of literature itself, or what I call the order of words" (ibid.).

Moreover, the attempted and innovative link with the structure of literature in this study could show how the Derridean approach can bring out the evolution of original and philosophical ideas in Shakespeare's plays. It will be observed how in Shakespeare's times ideas such as subjectivity, sexuality, social hierarchies, binary oppositions, hospitality and so forth served to shape people's thoughts and ways of life. In addition, some insights will hopefully result about how a sophisticated intellectual such as Shakespeare treated notions of law, religiosity, justice, race and class in his time. In this regard, therefore, the present study can introduce new insights and understanding to the body of Shakespearean scholarship. Further, although Derridean reading of Shakespeare's plays and poems is not a new phenomenon in the world of literature, there has been no attempt similar to this one in terms of the chosen texts and critical toolkit.

Since the focus of this paper is on three Shakespearean comedies in the light of Derrida's notion of deconstruction, it would be apt to review some of the studies conducted in these areas concerning themselves with deconstruction in Shakespeare's plays (tragedies or comedies), the analysis of the comedies from different deconstructionist viewpoints such as J. Hillis Miller's (Wolfreys, 2005), and even Derrida's own interpretation/deconstruction of Hamlet/Shakespeare. However, this paper chooses three comedies (Twelfth Night, Merchant of Venice, and As You Like It) and applies a Derridean deconstructionist approach to them, which has not been conducted as will be shown.

Marciano (2009) tries to pose and answer one question: why do we take Shakespeare's comedies seriously? She refers to Barbara Everett in order to clarify/justify her thesis and allots a dark side (which is known as the serious side) to Shakespeare's comedies. Her analysis is a thematic one which leads to a dark understanding of Shakespeare's play: 
Examining Shakespearean drama through the lens of Twelfth Night, then, we can respond to Everett's question as follows: a dark didacticism, an urgent sense that life must be lived well because it is short, often underlies Shakespeare's plays, and this principle, at least in part, accounts for the seriousness with which we regard Shakespeare's comedies (pp.5-6). She finally concludes that Everett's notion of the seriousness in Shakespeare's comedies should be taken seriously, for even in Twelfth Night as an example, such matters like death lead the consideration of living "wisely".

Woodbridge (1989) takes some of the play's seemingly eccentric (marginal/peripheral) scenes such as a speech on animal rights, intriguingly intimate relationship between two women, and an exploited agricultural laborer. Therefore, the questions of Marxist theory, feminism, gender criticism, ecocriticism and queer theory arise. Throughout the essay, she endeavors to approach the play from such theories.

Kitch (2009) presents a somehow political overview of the British and European understanding of the Jews, a history of their rise and fall, with an introduction that quotes Thomas Middleton's Triumphs of Honour and Industry. The book which was written in the early seventeenth century, as Kitch says, glorifies the "civilizing power of commerce". He goes on to study The Merchant of Venice and Marlowe's The Jew of Malta from these perspectives.

Derrida's own obsession with Shakespeare goes back to his book named Spectres of Marx (Derrida, 1994) where he addresses the Ghost of Hamlet's father and coins a new term, Hauntology. A "spectre is haunting Europe," Derrida once said. The Ghost of the father (yet another spectre) haunts Hamlet. Hamlet's specter haunts Marx and Derrida, while Shakespeare's spectre haunts English literature. Hauntolsogy is the term used by Derrida to refer to a historical/ontological change where a deferred past replaces the present. He quotes Hamlet's: "the time is out of joint". This is perhaps the vantage point of a Derridean (Deconstructive) outlook towards Shakespeare (by Derrida himself). Derrida states:

'Marx remains an immigrant chez nous, a glorious, sacred, accursed but still a clandestine immigrant as he was all his life. He belongs to a time of disjunction, to that "time out of joint" in which is inaugurated, laboriously, painfully, tragically, a new thinking of borders, a new experience of the house, the home, and the economy. Between earth and sky. One should not rush to make of the clandestine immigrant an illegal alien or, what always risks coming down to the same thing, to domesticate him. To neutralise him through naturalisation. To assimilate him so as to stop frightening oneself (making 
oneself fear) with him. He is not part of the family, but one should not send him back, once again, him too, to the border' (Spectres of Marx, p.29).

Whalley and Miller (2016) refer to Derrida's socio-political reading of Hamlet which could be in itself regarded as a deconstructionist reading:

'For Derrida, Hamlet is the pre-eminent hauntologic text. We are not asked to mourn Hamlet's death, we are asked to mourn those possibilities that his death removes. Through an extended discussion of Shakespeare's conflation of the existential (time) and the visceral (joint), Derrida considers how the optimism resulting from the fall of the Berlin wall, and the subsequent dissolution of the Soviet Union, allows for an interrogation of Marx's use of the term spectre in The Communist Manifesto, which Marx (with Engells) positioned linguistically as an always already disembodied political force. The fall of the wall affords Derrida the space to reflect that the Marxist project was built upon a ghost, thus causing him to question how one might mourn that which was never 'alive'" (p.30).

Hooti (2013) applies Derrida's theory of deconstruction to Hamlet using such keywords as binary oppositions, messianic, metaphysics of presence, aporia and difference. Bloom (2009) studies Shakespeare's comedies in fragments/aphorisms. He finds some moral attitudes in Bottom (from A Midsummer Night's Dream) by stating that: "One of Shakespeare's great originals, Bottom is not always well served by modern criticism, which tends to underestimate his innate dignity. Natural man, so much maligned by moralists, whether Christian or Marxist, achieves an apotheosis in Bottom" (p.2). He nominates Bottom as the ancestor of Joyce's Polly Bloom. Furthermore, he acknowledges Shylock's role in The Merchant of Venice, but feels obligated to say that it has done "grievous harm" to the Jewish society.

Shakespearean comedies have been approached by many critics and theoreticians from different perspectives. Derrida's deconstruction, therefore, is not an exception. The present study intends to apply some theories of Jacques Derrida to the comedies of Shakespeare which are full of uncertainty, phallocentrism, phallogocentrism, and even instances of Hauntology.

\section{The Present Study, Objectives and Underlying Methodology}

This study tries to read Shakespeare's selected comedies through a deconstructive framework, and referring to some of the related key concepts of deconstruction, sets out to analyze the chief characters within the context of the plays' chief events. 
It also aims at identifying how Shakespearean thought, conforms to, or departs from Derridean deconstruction. The selection of the elements of deconstruction is not a random one, but is simply based on their relevance to the demand of the text itself. It attempts to serve as a response to those who uncritically believe that deconstruction brings destruction upon the text and metaphysics in an arbitrary way. It is a support for the systematicity of deconstructive criticism as a way of 'decentering.' It shows the interplay of several meanings in the texts of modern-day culture and tries to expose some of the unspoken assumptions that play a role underneath some of the modern social thoughts. It also aims to add to the body of Shakespearean drama as a touchstone of Elizabethan literature to scrutinize how Derridean concepts can be applied to the literature of this period.

To explore the selected plays in this study, the author adopts a close reading of the texts, also involving comparisons and contrasts. Investigating Shakespeare's Pastoral comedy, As You Like It, his sarcastic tale of religiosity and trickery, The Merchant of Venice, and also his amusing comedy of identity confusions, Twelfth Night, this study compares and contrasts Shakespearean comedy in light of some Derridean texts such as Politics of Friendship, Rogues, and "Racism's Last Word". Firstly, the Derridean concepts of subjectivity, friendship, race and democracy and sovereignty will be elaborated. Along with it, Shakespearean ideas and concepts which are relevant to those of Derrida are introduced and buttressed through some meticulously chosen excerpts. Assuming that Derrida is in a habit of deconstructing the so-called established creeds, Shakespeare's texts are exposed to a deconstructive reading of the familiar (friendship \& democracy) to examine how these deceptively simple ideas are dealt with in his selected comedies.

Since this study aims to address the similarities and differences in Shakespeare and Derrida regarding the concerns mentioned above, a lot of comparisons will be made. For this purpose, firstly, Shakespeare's As You Like It will be investigated since it portrays great bonds of friendship and a noticeable issue of politics and democracy. Secondly, The Merchant of Venice will be elaborated on as a literary seat of the issue of race. Lastly, Twelfth Night as a monument of subjectivity and identity will be studied.

\section{Findings and Discussion}

\section{Applying Derridean Terms to the Text}

Derridean theory bears the potential to fit itself probably into every work of a literary imprint. Since he started to theorize his ideas in late 1960s, many critics have been 
applying the theories to literary pieces from the entire history of written literature and, in this regard, Shakespeare is no exception. Reading the comedies of Shakespeare under the paradigms of deconstruction was considered by Malcolm Evans in his brilliant Deconstructing Shakespeare's Comedies (2002). He points out that:

'.....And in all this concern with acting, representation and identity, so characteristic of the Comedies, the mirror that reflects deconstruction is always itself divided and already in more than one place - at the site of a mimetic sign or action, but also broken in the signifier released in the enactment of acting, the representation on the stage of the process of mimesis itself which may, as Holofernes maintains, be no more or less than 'nothing''(p.74).

The basis of his thesis here seems to be how the play itself allows deconstructive reading to happen. The act of dramatic representation/performance is undermined and challenged by the play itself, as if there is a window that allows the deconstruction of the play to take place; and this window exists in the play itself, Evans implies.

\section{Binary Oppositions in As You Like It}

This play is filled with replacements of centers, characters, authorities and even linguistic aspects. This is hinted by the act of parodying the very act of writing. To elaborate more, Orlando is joined by the Duke's men while he spends much of his time composing poetry for Rosalind. He goes so far as to carving her name into the trunk of many trees. Orlando also hangs his poems on the boughs of the trees probably hoping for Rosalind's seeing them; and she of course does despite being embarrassed about her name being seen everywhere. Now it is the turn for ridiculing this act of composition. Touchstone takes this burden to allow the play itself and the dramatic act to have a chance to comment on writing romantic poetry. Touchstone does this by battering the style of Orlando's poetry. On the other hand, when inquired by Rosalind, Celia tells her that Orlando is indeed the bard behind these poems. Meaning, that which is produced in reading act or performance, is a constant appearing of signifiers like those poems hanging from branches of trees. The poems being present everywhere and signifying the presence of Orlando everywhere and thus undermining phonocentrism. Moreover, like the poems, the play's world is a microcosm in which signifiers constantly replace one another leaving no logo or center authoritative or whole in its origin and content. Duke replaces duke, brother confronts brother over rights to rule or inhere fathers' legacy, cousin is to unseat 
cousin, fool topples oaf in the affections of Audrey, Ganymede supplants Silvius in those of Phebe; even genders replace each other in dramatic performance. A quite telling example of logo replacement is a short dialogue between Touchstone and Celia:

\section{TOUCHSTONE:}

The more pity that fools may not speak wisely what wise men do foolishly

\section{CELIA:}

By my troth, thou sayest true. For, since the little wit that fools have was silenced, the little foolery that wise men have makes a great show. (I. ii)

However, this does not mean that he is a logo or metaphysical presence having superiority over others. It is merely an indication that what is not within this signifiers' replacement, is actually only a very old and probably impotent duke huddling in exile. Name, a signifier, is what helps meaning further and dramatic action to be performed. Even Duke's exile in a cave in nature can be assumed as a return to savage roots away from civilization.

\section{Identity and Class}

Identity and social class have been of great importance for thinkers to reflect upon for centuries. Literature, being about human beings (or attributes) both as individuals and as groups, has always provided a ground for rethinking the notions of identity and class. The world of this play, though it seems to be of a very simple pastoral nature, is packed with complexities regarding ideology and social relations: "An examination of the representation of relations among different social classes in As You Like It, however, reveals that the connection between ideology and agency is neither simple nor uniform", according to Crane (2008). Moreover, to relate the issue of identity and decentering its ideological presuppositions to deconstructive reading, it must be considered how in this play replicas and substitutions challenge seemingly original and central concepts. This would be the pivotal point concerning ideologies being challenged in this play. As an instance, Duke Senior can be considered as the representative of feudal system ideology when he questions Orlando about his identity and then they are joined by Old Adam of whose presence Duke Senior is pleased. Both of them, the Duke and Adam, become focal characters in defining Orlando's identity. In other words, their gaze, the gaze of a royalty and a servant (subject) of royal families, becomes the ideological apparatus that defines Orlando. To the question, "who are you?" Orlando answers that he knows who he is. 
Getting to the notion of ideology, it is to be noted that what ideology implies here is not the definition provided by Marx and Engels as "false consciousness". Rather, it refers to the invisible relations between the subjects of a system that connects them together and creates an integrated whole. Schleiner (1999: p.287) considers ideology in this play and by extrapolation, in generality of the modern era to involve 'systems of discursive effects organizing conflict, negotiation and cooperation among people interacting around some institution or set of linked institutions, effects including beliefs and generic subject positions whereby speech, texts and other productions are infused with import and sustenance.' Going back to Derrida and the matter of institutions (political, philosophical, theological, social, and so forth) and their relationship with literature, McQuillan (2003) remarks on Derrida's view on literature. He asserts that literature, and particularly fiction genre, is an unconditional institution, an institutionless institution that allows subjects, authors, readers, etc. to say anything and to criticize every other institution. In this Shakespearean comedy, it is noticeable that by disguise or satirizing royalty, ideologies related to feudal values, Renaissance virtues, and even women as inferior gender are subverted. Take this into account as an instance:
ADAM:
What, my young master! O my gentle master,
O my sweet master, $O$ you memory
Of old Sir Roland, why, what make you here? [...]
$O$ what a world is this when what is comely

\section{Envenoms him that bears it! (II.iii.2-15)}

In the eyes of Adam, as an old servant to the royalty and probably the epitome of feudal way of thinking, Orlando is worthy and praiseworthy not because he has royal blood of the nobility; on the contrary, Orlando is great and virtuous for he has been so and has virtues and personality features in the story and the dramatic action that prove him to be noble. The common sense and probably reason of that time suggests that peasant and royalty are two distinct classes that should never mingle except for what traditions, conventions and ideologies allow. This passes down and through generation after generation through blood and birthright. This is a utilization or abuse of reason in a Kantian sense since, after all, many things are a priori, like nobilities' supremacy over the lower classes. "......the bigger problem with utilitarian notion of Reason is that it is end-orientated. That is, it is pragmatic, strategic and objectively focused 'in view of its utilization"” (Derrida, 1983: p.11). Derrida suggests that 
utilization is potentially a problem because 'thinking 'or 'thought' in general, and by implication ethical response, becomes simply a techno-scientific program producing or authorizing particular discourses that serve 'technopolitical' powers (Derrida, 1983: p.18).

\section{Aporia}

As stated in chapter 2, the concept of aporia means "without passage" in Greek and it refers to the doubts left in the literary text which compel the reader to make his or her own judgements. In other words, aporia is a deadlock caused by an internal paradox in a situation that cannot end in a dialectical synthesis in itself. When it comes to decisions, aporetic situations lead to undecidability and thereby hinder the birth of any new decisions.

In the play, there is a conversation between Celia and Rosalind in which they ask Orlando to give over the wrestling challenge. Orlando's reply and speech regarding his position is quite opaque:

- ORLANDO, I beseech you, punish me not with your hard thoughts, wherein I confess me much guilty to deny so fair and excellent ladies anything. But let your fair eyes and gentle wishes go with me to my trial, wherein, if I be foiled, there is but one shamed that was never gracious; if killed, but one dead that was willing to be so. I shall do my friends no wrong, for I have none to lament me; the world no injury, for in it I have nothing. Only in the world I fill up a place which may be better supplied when I have made it empty. (I. ii)

Although asked to turn down the challenge by the ladies as they obviously care about him, Orlando rejects their request by stating that he is not going to be missed by anyone and even though he claims to be willing to dead, he asks Celia and Rosalind to wish him good luck. This speech in its entirety demonstrates Orlando's naïve thoughts on existence and his inability to recognize his being as worthy or unworthy.

\section{Pharmakon}

Derrida's idea of pharmakon, the concept first introduced by Plato bearing the two opposing connotations of poison and remedy, is to clarify the conditions in which the opposition of the binaries is produced and a phenomenon is preferred to its counterpart, i.e. how the preference is given to either the remedial or the poisonous 
aspects of a phenomenon in a context. As You Like It delivers a vivid example of a pharmakonic situation in which a character takes into account the negative aspects of phenomena generally considered good and the positive points of phenomena normally regarded bad/evil:

\section{DUKE SENIOR:}

Now, my co-mates and brothers in exile,

Hath not old custom made this life more sweet

Than that of painted pomp? Are not these woods

More free from peril than the envious court? [...]

And this our life, exempt from public haunt,

Finds tongues in trees, books in the running brooks,

Sermons in stones, and good in everything. (II.i.1-17)

In these lines, Duke Senior prefers the woods with all its wild inhabitants over a court with all its guards and the safety its fortress offers for he sees no danger greater than the hypocrisy that prevails in the court. In other words, he believes the threats they may face in the woods is worth keeping away from the poisonous security the court brings.

\section{Forgiveness}

Derrida discusses the issue of forgiveness, arguing that genuine forgiveness must involve the unforgivable: that is, the forgiving of an 'unforgivable' transgression - or a 'mortal sin' as Derrida puts it (p.32). He also believes that forgiving must be irrational, or as he asserts, "mad" (pp.39,49). This sheer forgiveness, he argues, excludes the necessity of an apology or repentance on the part of the guilty person. Derrida believes that if one forgives that which is forgivable, one is engaged in calculative reasoning and is, in fact, not forgiving. Any form of apology or forgiving of forgivable is dubbed reconciliation and not real forgiveness. Derrida argues that real forgiveness involves only two entities: the guilty and the victim. The intervention of any third party would change it into reconciliation even if this third party is language itself. This causes forgiveness to possess an aporetic nature. On the one hand, it must involve only two parties; on the other, two parties cannot fulfill it without the intervention of a third party. The third party, however, is always present 
in these three plays: law, religion, friendship, love, and so forth, all play the role of the intervening element that hinder the arrival of Derridean forgiveness. But this lack of a Derridean term helps this research understand the concept of aporetic moments better; the non-passage that brings about a forced decision making. For example, in As You Like It, Duke Frederick can't but perform an aporetic forgiveness that would show the entangles of the characters:

DUKE FREDERICK Send to his brother:

'Fetch that gallant hither.'

If he be absent, bring his brother to me -

I'll make him find him. Do this suddenly,

\section{And let not search and inquisition quail}

To bring again these foolish runaways. (II.iii.17-21)

The comedy is today accounted for as one of Shakespeare's most notable works not merely due to the creation of jolly, full-grown characters or outstanding heroine, but also because of the social and 'off-text' connotations of the play. The story revolves around the axis of cross-dressing (as do the plots of The Merchant of Venice, As You Like It, inter alia) that enables the author to easily swing between different characters and situations. The shipwreck that happens in the opening scene, the falling apart of the twin siblings, Viola and Sebastian, and Orsino's burning love for Olivia sets the tone for the rest of the play. The dejected Viola disguises herself as a young "boy" named Cesario. It is worth mentioning that, in Shakespeare's time, Cesario was a general nomenclature for those male actors in disguise who were cast as women in plays. Meanwhile, Cesario is sent by the Duke to Olivia who is mourning for the death of her brother and who has banned herself from the company of men for seven years, to give her his love message. Surprisingly, the mourning lady falls for Cesario, who has respectively fallen for Orsino. This intricate web of love and yearning becomes even more sophisticated with the arrival of Sebastian, whom we conceive to be saved from the roaring waves by a sea captain (Antonio). His reappearance adds to the confusion of the play (since Cesario/Viola and Sebastian are identically similar in countenance) but eventually unties the story's knot by his unification to Olivia, which is followed naturally by his sister's marriage to Duke Orsino.

Apart from the main storyline, the significance of the play also lies in its well-knit subplots, among them Malvolio's mishap and his manipulation by his fellow servants, the enmity between Antonio and Duke Orsino and even Sir Andrew Aguecheek's follies, all of which contribute to main plot's progression. Molvolio, a 
rigid, bitter head servant, is beguiled into believing that Countess Olivia has some feelings for him. Quite surprised and happy, he wears yellow stockings and an artificial grin to be what he thinks Olivia asks him to be (in a feigned letter). When he figures out that the whole story was a mere chicanery, he emotionally breaks down and swears revenge.

Twelfth Night's complications, the manipulations of the concept of self through its transvestite inclinations, and the prominent role of the heroines, among other things, makes the play a fertile ground for deconstructive studies, since different aspects of the play tend to defamiliarize the long-held concepts of comedy up to Shakespeare's day. According to the play's genre and its plot, the researcher chose to apply a certain number of Derridean terms which seemed to be more appropriate. Duly, the notion and function of double meaning and binary oppositions is presented first. Secondly, there will be a focus on the concept of friendship in Twelfth Night within a deconstructive framework. This will be followed by the subjects' identity and gender roles. Finally, the aporetic, undecidable moments of the play will be examined.

\section{Binary Opposition in Twelfth Night}

In his Margins of philosophy (1982), Derrida reconsiders the concept of binary oppositions asserting that the two sides of an opposing binary are not equally measured but only put into a hierarchy, "An opposition of metaphysical concepts (speech/writing, presence/absence, etc.) is never the face-to-face of two terms, but a hierarchy and an order of subordination" (p.195).

He goes on to describe that in order to overcome this taken-for-granted hierarchy, these classical oppositions must, at the first step, be toppled and then displaced, "Deconstruction cannot limit itself or proceed immediately to neutralization: it must, by means of a double gesture, a double science, a double writing, practice an overturning of the classical opposition, and a general displacement of the system. It is on that condition alone that deconstruction will provide the means of intervening in the field of oppositions it criticizes" (Ibid). This deconstructive process is roughly traceable within some moments and scenes of the play, which makes the play an apt case for the study of deconstruction.

The fundamental binary opposition of man/woman accounts for almost every incident of Twelfth Night. As usual, men are considered more potent and appropriate for different social positions and are prioritized in various situations. Orsino, not knowing that Cesario is in fact a woman, sends a man to Olivia to express his love. Viola disguises herself as a man to be able to enter the Duke's house. Molvolio, an 
uncompromising man, is chosen to be the head of the servants in Olivia's house. Sir Toby, the Countess's uncle, indulges in revelry and carousing with little or no prohibitions and Olivia considers it necessary to mourn 7 years for the death of a male family member. Despite all these binary oppositions between men and women, Shakespeare tends to displace all of them. This time, he prioritizes women over men, to show the shaky foundations of these hierarchies: Orsino, a powerful Duke who is capable of inactivating Antonio, is constantly enchained by a female's love (first of Olivia and then that of Viola),

\section{ORSINO:}

There is no woman's sides

Can bide the beating of so strong a passion

As love doth give my heart. No woman's heart

So big, to hold so much. They lack retention. (.....)

\section{Make no compare}

\section{Between that love a woman can bear me}

And that I owe Olivia. (II.iv.91-101),

The main character of the play is chosen to be women and he is given two roles at the same time, only to emphasize her abilities. Also, Viola's intelligence is contrasted to the folly and idiocy of some characters like Sir Andrew Aguecheek and even her brother's passivity (Sebastian accepts Olivia's love with no further questions about the reason of this sudden surge of love). Moreover, Molvolio is tantalized through the plan of Maria, Olivia's chambermaid, and the fake love letter she writes on behalf of the countess. In his Shakespeare's Festive Comedies, François Laroque mentions this contrast, i.e. mental acuity of women and the men's stupidity: "The comic resolution is not achieved through fidelity, but through fluidity or flexibility, as Olivia is quite happy to take Sebastian for Viola and Orsino CesarioViola for Olivia. At the same time, unequitable desire is exposed and stigmatized in Aguecheek and Malvolio, who embody the antitypes of hypocritical restraint on the one hand, and ridiculous excess on the other" (A Companion to Shakespeare's Works Volume III, p.42). By subverting the man/woman hierarchy and changing it into woman/man, Shakespeare openly repudiates this hierarchy (at least in this play) and seems to be in tandem with Derridean ideas. Courtiers/commoners is another major binary opposition in Shakespeare's Twelfth Night. The whole action of the play unfolds within the context of court. Both Orsino and Olivia are presented as 
members of nobility. Meanwhile, other characters, even Viola herself, hold a respect for the nobility (even if it is solely on the surface) and act according to its will. In a discussion with Cesario, Orsino asserts that no one other than a courtier is fit for his love while also giving his views on the general concept of love in men and women. He openly names Olivia as a distinguished countess who is incomparable to other women.

\section{Friendship in Twelfth Night}

A general review of the Shakespearean comedies proves how dependent they are on the friendly bonds between the characters. Bassanio and Antonio in The Merchant of Venice, Rosalind and Celia in As You Like It, Proteus and Valentine in The Two Gentlemen of Verona, Palamon and Arcite in Two Noble Kinsmen and even the friendly relationship between Don Pedro and Leonato in Much Ado About Nothing. Like other comedies, Twelfth Night draws upon the issue of friendship and friendly relations to strengthen its storyline. In his Politics of Friendship (1997), Derrida explores the idea of friendship and, duly, deconstructs the "reciprocity" of friendship, among other themes. Firstly, he shows how this theme has been an integral part of philosophy and literature throughout history from Plato and Aristotle to Nietzsche; then he exposes the long-held beliefs for friendship. He maintains that there are no such rigid boundaries of 'friendship' and 'enmity' and that 'the two concepts (friend/enemy) consequently intersect and ceaselessly change places. They intertwine as though they loved each other" (p.72). Therefore, he believes, we have no predefined concept of friend or enemy and even sometimes an enemy can be more beneficial than a friend; in other words, "the true enemy is a better friend than the friend. For the enemy can hate or wage war on me in the name of friendship, for friendship's sake, out of friendship for friendship; if in sum he respects the true name of friendship, he will respect my own name." (Ibid). Hence, for Derrida, fiends are not necessarily on the same way; sometimes a friend can be quite different in goal or proposition (enemy).

Shakespeare designs friendly dealings to be so heterogeneous that one must be extremely hesitant, for example, to call Hamlet and Claudius enemies or friends. In Twelfth Night, the friendships between the characters do not follow the same pattern as well and the position of the enemy and the friend is incessantly challenged and replaced. At times, someone who dearly loves someone else is not loved reciprocally and a person who is deemed enemy turns out to be a friend. 
Duke Orsino's friendship to Cesario seems to be a pure reciprocal relationship; he lets Cesario in his house and Cesario agrees to woo Olivia for him, which at first Viola tries to shun but accepts at last when she sees Orsino's passion:

\section{DUKE:}

Stand you a while aloof. Cesario,

Thou know'st no less but all. I have unclasp'd (.......)

And tell them, there thy fixed foot shall grow

Till thou have audience.

VIOLA:

Sure, my noble lord,

if she be so abandon'd to her sorrow

As it is spoke, she never will admit me (I.iv.11_21).

This reciprocity is totally subverted at the end of the story and Orsino, having faced an unrequited love, only wants to see her in her female garments (v.i.265_266). With this in mind, a purely usual friendship has turned into a burning love relationship.

\section{Identity and Gender Roles in Twelfth Night}

The question of gender is quite evident in Twelfth Night, as it is within Shakespeare's other cross-dressing comedies. When Viola dresses herself as Cesario, the audience cannot help accepting her as a male character even though she is called "Viola" and even when she takes on a male role. Commenting on Derrida's innovation in the definition of gender and sexuality, Jonathan Crimmins (2009) explains how he utilized and broke away from Hegelian notion of sexuality. Derrida spliced his thought into Hegel's description of copulation as the relief of sexual difference, and produced an analysis that not only highlighted the equal participation of the genders, but also recast the relieving of sexual difference not as a loss of gender but rather as a surplus of gender, a mutual bisexuality" (p.56).

Hence, Derrida believes that gender, identity and sexuality are defined beyond the traditional boundaries of man/woman and must be regarded as a notion within which the footsteps of both sexes can be traced. Shakespeare manages to create that 
'asexual' atmosphere by means of a number of techniques (cross-dressing, for example), and ambidextrously generates the cooperation between the sexes, i.e. a mutual bisexuality. In the following excerpt for instance, his pungent words are simultaneously pointed at Olivia (the female love object), Orsino (the male lover) and Viola (whom Feste thinks to be the third part of the love triangle):

VIOLA:

Art not thou the Lady Olivia's fool?

\section{CLOWN:}

No, indeed, sir; the Lady Olivia has no folly. She will keep no fool, sir, till she be married; and fools are as like husbands as pilchards are to herrings; the husband's the bigger.

I am indeed not her fool, but her corrupter of words (III.i.30-35)

Apart from Feste, Shakespeare also manages to intermingle the roles and attributions (and even attires) of both sexes within Viola. In other words, throughout the play, Viola is both a man and a woman, even though the audience know, through a dramatic irony, that a woman is behind all the role play. By disguising as a man, thus, she falls into the Derridean category of the mutual relationship of both sexes and creates a theoretical bisexuality within herself. To be precise, gender becomes an empty signifier that hosts both Olivia and Cesario and oscillates between them. The audience tend to see her as a man when she plays Cesario because she successfully meets the requirements of a man's appearance: She manages to woo a female, fights with Sir Andrew Aguecheek (III.iv) and wins Orsino's trust as a confidant. A woman wearing a man's clothes is also a deconstructive way of considering gender and gender attributions in early seventeenth-century England where costume spoke not only for gender but also for class. As Ford (2006) comments, "In a culture so rigorously preoccupied with clothing standards that it needed to publish a succession of sumptuary laws for men and women, Twelfth Night's many disguises offered, not only to the characters within the play but to the early modern audiences watching those characters, the opportunity to test out a world."

\section{Decision and Decision Making}

One of Derrida's fundamental issues revolves around the concept of decision. $\mathrm{He}$ believes that the nature of the decision is aporetic, that is, contradictory. Despite the 
fact that making a decision presupposes thinking and planning, Derrida asserts that it must be mad, frenzy and without calculation. Drawing on the Danish philosopher, Kierkegaard, Derrida mentions the necessity of discarding all of the common prerequisites of a decision. In Deconstruction and the Possibility of Justice (1992), Derrida sketches out the characteristics of a deconstructive decision:

"A just decision is always required immediately, "right away." It cannot furnish itself with infinite information and the unlimited knowledge of conditions, rules or hypothetical imperatives that could justify it. And even if it did have all that at its disposal, even if it did give itself the time, all the time and the necessary facts about the matter, the moment of decision, as such, always remains a finite moment of urgency and precipitation, since it must not be the consequence or the effect of this theoretical or historical knowledge, of this reflection or this deliberation, since it always marks the interruption of the juridico-or ethico- or politico-cognitive deliberation that precedes it, that must precede it' (p.26).

Elsewhere in his Gift of Death (Derrida, 1995), he mentions Abrahams's "incommensurable" love for his son, Isaac, and exemplifies Abraham's mad decision (p.65). Derrida believes a decision must touch upon what is outside of one's control. He deems a decision philosophically authentic that is impossible by itself and necessary all at once. Shakespeare's Twelfth Night is also imbued with the same sense of decision in some cases. Some of the decisions are purely deconstructive in their natures, being both mad and necessary. After Olivia falls in love with Cesario, she suddenly decides to send her beloved a ring, a decision which has the element of "immediacy" and yet is quite necessary to bring back the messenger. The Countess, let alone a mourning one, should not send any love sign or message to anyone, let alone a man of humbler origin. However, on a moment of madness she decides to take the action:

OLIVIA:

Run after that same peevish messenger,

The county's man. He left this ring behind him,

Would I or not. Tell him I'll none of it.'

OLIVIA hands him a ring

"Desire him not to flatter with his lord,

Nor hold him up with hopes. I am not for him. 
If that the youth will come this way tomorrow, I'll give him reasons for't. Hie thee, Malvolio. (I.i.274-281)

Antonio's sudden and mad decision to defend Cesario (whom he mistakes for Sebastian) against Sir Andrew Aguecheek can be considered as another example of Derridean decisions. Being chased by Orsino's officers, Antonio intervenes, saves Viola and is eventually caught by the officers. Despite the fact that he is in a terrible situation, he decides to save his beloved. Antonio's decision doesn't follow his personal benefit (which necessitates that he saves his own life) and is totally out of his control.

\section{The Merchant of Venice, History and Singularity of Literature: Does Shakespeare Challenge Fixated Identities?}

The history of Shakespearean scholarly studies, history-wise, has it that this masterpiece which is indeed a plethora of different ideologies and Renaissance values was written between 1596 and 1598 and was not published in print form until 1600. It is an enchanting story from early modern Italy that includes interesting studies of the character of man in the form of drama. The play covers the unmatched cruelty of Shylock the Jew towards Antonio wanting to pound of his flesh as the compensation for the loan borrowed for Bassanio, and Portia's condition for her suitors that they have to choose among three chests, all as the parts of the magnificent play wrought by the soul of the age; his age. It is not one single story or idea that we face in this well-wrought text. Rather, it is a scale on which history and ideology of a critical era is presented. The play has been adjudicated on many bases. Ideology, anti-Semitism, measures of a modern man, religious and theocratic concerns and so forth are among those bases.

\section{Reading the Merchant of Venice through Aporetic Hospitality and Identity}

As the Merchant of Venice presents a number of hospitality scenes, it seems to be a fine piece of work for the scrutiny of hospitality from the deconstructive standpoint. Overall, hospitality is categorized among Derridean aporia, whereby the nature of the concept upholds a tension, a contradiction. In Derridean terms, hospitality involves a strong sense of altruism in which the host gives up whatever he possesses. "Despite all the tensions or contradictions which distinguish it, and despite all the perversions that can befall it, one cannot speak of cultivating an ethic of hospitality 
(Derrida, 2001: p.16). Moreover, he asserts that apart from giving up the possessions, the aporetic nature of hospitality lies within the impossibility of giving up the house's control: if you are the host, you have the control (which Derrida deems is not real hospitality). If you are not in house's control, then you are not the host. Derrida (2000) states that hospitality is an impossible aporia never to be resolved and always within a dilemma: "We will always be threatened by this dilemma between, on the one hand, unconditional hospitality that dispenses with law, duty, or even politics, and, on the other, hospitality circumscribed by law and duty. One of them can always corrupt the other, and this capacity for perversion remains irreducible" (p.135).

An according to Wortham's (2010) reading of Derrida, offering welcome, when Derrida himself is doing at the beginning of his speech, assuredly dictates that the welcomer is abidingly at home or in their element. "To welcome is therefore not only a matter of giving room to, or making space for, the other; it also allows the welcomer to, in effect, police the threshold, to commandeer the site of welcoming for themselves, and thus to establish precedence over the other to whom the welcome is extended" (p.71). Thus the other is taken into control by the welcome. However, as Wortham continues, "One must therefore seek to keep open the possibility of hospitality in its unconditional form, as an opening to the wholly other, the unwelcomable guest, the absolutely unanticipatable arrivant" (p.72).

In The Merchant of Venice, accepting, welcoming, abiding, and even terrorizing the other is a prevailing theme. The following lines of Shylock shows how being a Jewish is an unwelcome status in the Christian community:

'I am a Jew. Hath not a Jew eyes? Hath not a Jew hands, organs, dimensions, senses, affections, passions; fed with the same food, hurt with the same weapons, subject to the same diseases, healed by the same means, warmed and cooled by the same winter and summer as a Christian is? If you prick us do we not bleed? If you tickle us do we not laugh? If you poison us do we not die? And if you wrong us shall we not revenge? If we are like you in the rest, we will resemble you in that. If a Jew wrong a Christian, what is his humility? Revenge. If a Christian wrong a Jew, what should his sufferance be by Christian example? Why, revenge. The villainy you teach me I will execute, and it shall go hard but I will better the instruction' (III.i.49-61).

No other unsettling section in the entirety of Shakespeare's oeuvre can delineate the otherness as well as this speech of Shylock's. Here he declares to Solanio and Salarino that he will undo the evils that have befallen him. Shylock strongly argues that all members of the society are humans equally no matter to what religious sect they belong. In other words, Jews as a minority in Venice of that epoch are though 
accepted partially into the society, still monitored and excluded from the whole. Jews are accepted under certain conditions. Shylock points out that all Jews and Christians possess the same human features and characteristic. Feelings, reason, rational, emotions and hate are all the same prevailing in their soul and spirit. While Shylock's argument seems pretty sound and rational to our ears, in that time, with those sorts of prejudice in the air, his claims could be interpreted as a call for an unconditional hospitality of a political and ethnical kind not to mention their theological nature.

\section{Messianism in the Merchant of Venice}

The Messiah is a religious savior. It is how people use and mostly misuse religion to get benefit. The Messiah is similar to manipulation in which a person tries to achieve her own benefits usually through illegitimate trends. Many believe that religion should be considered as the base of all knowledge and stories. Many writers try to use religion in a way in their texts; however, it is very important for a writer not just to focus on the religion that she believes in. That is because in that case the universality of literature will come under question. The Messiah is closely related to the concept of Grand-narratives in postmodernism as it also deals with deep-rooted beliefs and ideologies, usually religious in a society. The Messiah acts as a "Mr. Right" which means that writers and politicians who use it try to manipulate people into believing that what they are arguing is valid as it is based on religious ideologies. However, the Messiah can act as a facilitator if it is utilized appropriately by referring to the commonalities among religions and discussing such concepts without trying to argue that there is a "better" religion.

In literature in general and stories in particular, thanks to the nature of the characters and their roles in a text, a writer can hide himself and let the characters bring about the concepts related to religion and use it as a savior. In that case, the writer can provide two sorts of characters and by referring to the similarities and differences of religions and introducing the key common concepts, lead the story toward universalism. This perhaps is most tangible in the case of Portia in The Merchant of Venice. It can be see that while both Shylock and his Catholic opponents/oppressors cling to their grand-narrative of religious authority, truth, and juridical law and creating phantasmal savior, by undermining grand-narratives of religion and theocratic laws as well as patriarchal identity/authority, Portia challenges and decenters false claims of Messianic transcendental signification. However, Portia is not totally without messianic belief as she tries to convince Shylock to show mercy for mercy is an attribute of the Christian God:

\section{Portia:}


Then must the Jew be merciful.

\section{Shylock:}

On what compulsion must I? Tell me that.

\section{Portia:}

The quality of mercy is not strained,

But mercy is above this sceptred sway,

It is enthronèd in the hearts of kings,

It is an attribute to God himself. Act 4, Scene 1, 179-192

\section{Gift}

Like Forgiveness, the concept of gift is of an aporetic nature. Derrida exempts true gift from the ordinary give and take. He believes that the genuine gift precludes any possibility of need which annuls the gift. Even a simple 'thank-you' for instance, which both acknowledges the existence of a gift and also offers some form of equivalence with that gift, can be seen to nullify the gift. This little sentence takes the sentence into the cycle of give and take. For Derrida, a genuine gift needs its giver to be anonymous so that there is no benefit in giving. Portia, for example, intervenes in the court and turns the tables in favor of Antonio's friend, so she could be considered a true gift giver since she expects almost nothing in return. Her love for Antonio is a naïve affection, in a positive sense, because of the fact that she requires almost nothing in return. On the other hand, the sense of an aporetic gift, as an instance, is tangible in the following lines for example:

\section{Portia:}

Art thou contented, Jew? What dost thou say?

\section{Shylock:}

I am content.

\section{PORTIA (to NERISSA)}


Clerk, draw a deed of gift.

\section{Shylock:}

I pray you give me leave to go from hence.

am not well, send the deed186 after me,

And I will sign it.

Duke Get thee gone, but do it. Act 4, scene 1, 390-394.

\section{Pharmakon in the Merchant of Venice}

Moreover, Shylock's speech and his situation as well as his later conundrum at the court of law could be a resonance of Derrida's concept of pharmakonic bodies. Civil law in Venetian society of that age along with religious decrees could be considered as pharmakons: "at once medicine and poison, a supplement that may be both remedial and toxic, a 'good' and 'bad' drug at once" (Wortham, 2010: p.41):

\section{PORTIA:}

The law hath yet another hold on you.

It is enacted in the laws of Venice,

If it be prov'd against an alien

That by direct or indirect attempts

He seek the life of any citizen,

The party 'gainst the which he doth contrive

Shall seize one half his goods; the other half

Comes to the privy coffer of the state;

And the offender's life lies in the mercy

Of the duke only, 'gainst all other voice.

In which predicament, I say, thou stand'st; 
For it appears by manifest proceeding

That indirectly, and directly too,

Thou hast contrived against the very life

Of the defendant; and thou hast incurr'd

The danger formerly by me rehears'd.

Down, therefore, and beg mercy of the duke. (IV.i)

At first glance sympathizing with Shylock or the Jews seems to be rather odd or of unjust nature particularly when close to the end of the play we witness Shylock's cruelty towards his victim. And holding this disposition, it certainly is justified to consider law as the remedy and shylock as the 'Other' as the poison for the body which is the Venetian society as a Catholic whole. On the other hand, when looking at the events through Shylock and Jews' eyes, it is obvious that the cruelty towards this other or minority is a long unjust tradition in Venice or other societies of that time. In the performance of this play and the concepts of mimesis in general, it can be observed that "Mimesis, in its Platonic sense, is marked by an internal division between that which conceals 'truth' with its false likeness, and that which unveils, reveals, refers to, relifts and relieves 'truth' itself'.

One of the truths that lies at the heart of this play seems to be how the process of making a minority as a poisonous other is embedded even in the laws of a society. The poison which is the bondage and discrimination against 'other' is so naturalized as a justified purity that has penetrated the remedy; civil law or the court of justice. "Thus, the very concept of mimesis in Plato duplicates or repeats itself - writes itself - in an ambivalent and always supplementary way" (Wortham, 2010: p.44). Hence, in this sense, justice and law act as pharmakon in supplementary ways as well.

\section{Conclusions}

Analyzing the chief characters within the context of three of the most significant comedies of William Shakespeare, As You Like It, Twelfth Night, and The Merchant of Venice, this paper tried to shed light upon the unseen aspects of Shakespeare as a playwright through a deconstructive framework, and referring to some of the related key concepts of deconstruction. As a playwright, Shakespeare appears to be less conservative toward the conventions of the society in his comedies in comparison with his tragedies and histories. 
In his comedies (the three selected ones here in particular), Shakespeare tends to undermine the social conventions and hierarchies, a tendency not as tangible in his tragedies and histories. These subversions of widely accepted hierarchical conventions, however, are done in such an acute way that becomes almost impossible to notice without the help of Derrida's theoretical framework. Derridean concepts give us not only the opportunity to realize how wobbly the bases of such hierarchies are, but they can also provide us with a more reliable portrait of Shakespeare as a social subject.

By analyzing As You Like It through a close reading in the light of some of Derrida's key concepts, including subversion of binary oppositions, the questions of identity and class, the aporetic nature of decisions, and also the pharmakonic nature of the world around, it is easy to discover that Shakespeare was obsessed with philosophical and subjective issues as well as social and cultural ones. In this play, according to the theoretical terms mentioned above, peasants and nobles mingle due to Orlando and Adam's relationship, Orlando cannot decide whether he is worth surviving or not, and Duke Senior prefers the wild woods over the safe court to flee hypocrisy.

Shakespeare continues undermining the social hierarchies in Twelfth Night which we looked at above. The Derridean notions applied in this play, once again, reveal Shakespeare's covert rebellion against cultural conventions of the society. The binary operations are subverted when women are given the upper hand over men; the concepts of friendship/enmity are contemplated when its different forms are explored in the play; identity and gender are questioned when roles are taken and dresses are changed; and the nature of decision is demonstrated when characters have to make up their minds abruptly despite all prior planning and thoughts.

Also, The Merchant of Venice was analyzed and read through some more Derridean terms. The terms applied here can also be categorized under individual and social tabs. Shylock becomes a bulletin board for the otherness which is understandable through Derrida's arguments on identity and hospitability; justice is pharmakonic when law becomes an obstacle in the way of justice; Messianism explains the characters' anticipation of a "coming" of the opaque character; difference is when Morocco's analogies of what things are and are not is recited; and the undecidability of all decisions is shown when the logic behind decisions is questioned.

All the Derridean terms applied on these three plays, as summarized above, are geared to expatiating on the individual and social aspects of characters' lives. Armed with Derridean insights, one can see and account for the difficulty besetting the subject to recognize and appreciate their behavior as well as for how social principles 
are merely cultural contracts rather than objective facts. One can also find that individual behaviors are not that logical, nor are social norms that rigid and unchangeable. But the aspect that can only be found in Shakespeare's comedies, not in his tragedies and histories, is the social one. Shakespeare's subtle attack on social conventions in his comedies can also provide us with some rough clues as to his own personality.

The foremost conclusion that can be drawn from this study is that Shakespeare himself was a person obsessed more with social aspects of life than religious or philosophical ones since he barely approached those two aspects of a character's life in any of the selected comedies. Through exploring and multiple uses of subversion of binary oppositions, identity, gender, class, decision-making, pharmakon, friendship, hospitability, Messianism, difference, and undecidability, Shakespeare provides his audience with a hint of what he himself is like: an intellectual social subject highly skilled at questioning whatever is widely accepted and regarded as being solid and never-changing. This inference from the works affording a glimpse of the author's personality in real life can also be regarded as another insight indirectly emerging from this research.

There are some limitations to this study, both in selected works and theoretical framework, that are to be taken into account. The selected works are Shakespeare's lesser known comedies. The selection of the elements of deconstruction was not a random one, but was simply based on their relevance to the demand of the texts in question.

For further studies, in order to enhance the conclusions drawn in this study and achieve a portrait as accurate as possible of Shakespeare's personality, researchers are strongly suggested to apply the selected theoretical concepts here to Shakespeare's tragedies and histories. Another suggestion for further research is to use other Derridean terms for the selected comedies in this study to achieve a more tangible and inclusive appreciation of William Shakespeare's character through his works. Yet other avenues of analysis could involve the psychodynamics of feelings in the literary work (Ashraf, 2017) and the probing of such social considerations as class oppression (Omrani et al, 2016).

\section{References}

Abjadian, A. (2002). A survey of English literature. Tehran: SAMT.

Abrams, M., Abrams, M., \& Harpham, G. G. (2011). A glossary of literary terms. Wadsworth Cengage Learning. 
Ashraf, R. (2017). Psychodynamics of Mother Daughter Relationship: Degrees of Deprivation, Oppression and Dispossession in Doris Lessing's Fiction. Khazar Journal of Humanities and Social Sciences, 20 (1), 77-91. DOI: 10.5782/22232621.2017.20.1.77

Balkin, J.M. (1987). Deconstructive Practice and Legal Theory. 96 Yale L.J. 743.

Balkin, J.M. (1989). The Footnote. 83 Northwestern Univ. L. Rev. 275.

Balkin, J.M. (1990a). Nested Oppositions. 99 Yale Law Journal 1669.

Balkin, J.M. (1990b). Tradition, Betrayal, and the Politics of Deconstruction. 11 Cardozo L. Rev. 1113.

Bloom, H. (2003). William Shakespeare's As You Like It (Bloom's Modern Critical Interpretations). New York: Chelsea House Pub.

Bloom, H. (2009). William Shakespeare: Comedies. Blooms Literary Criticism.

Christoffel, M. \& Niekerk, V. (2005). Shakespearian play: deconstructive readings of The Merchant of Venice, The Tempest, Measure for Measure and Hamlet. Dissertation (MA (English)). Retrieved from http://hdl.handle.net/2263/29329

Cixous, H. \& Milesi, L. (2012). Shakespeare Ghosting Derrida. (1. milesi, Trans.). United Kingdom: Edinburgh University Press.

Colebrook, C. (2014). Jacques Derrida: Key Concepts. London: Routledge.

Coward, H. (1991). Derrida and Indian Philosophy. State University of New York Press.

Crane, M. (1955). Twelfth Night and Shakespearean Comedy. 6, 1-8. doi:10.2307/2866046

Crane, M. (2008). Linguistic Change, Theatrical Practice, and the Ideologies of Status in "As You Like It" (Vol. 27). The University of Chicago Press. doi:10.2307/43447760

Crimmins, J. (2009). Gender, Genre, and the Near Future in Derrida's "The Law of Genre. Diacritics, 39, 45-60. Retrieved from https://www.jstor.org/stable/41416227

Critchley, S. (2003). Deconstruction and Pragmatism. London: Routledge.

Critchley, S. (2014). The Ethics of Deconstruction: Derrida and Levinas ( $3^{\text {rd }}$ ed.). Edinburgh:

Edinburgh University Press. doi:10.1086/686969

Cuddon, J. A. (2013). Literary terms and literary theory. Wiley-Blackwell. doi:0.1002/9781118325988

Dalton, C. (1985). An Essay in the Deconstruction of Contract Law. 94 Yale L.J. 997.

Demastes, W. W. (2008). Comedy Matters: From Shakespeare to Stoppard. Palgrave MacMillan.

Derrida, J. (1973). Speech and Phenomena: And Other Essays on Husserl's Theory of Signs. (D. B.

Allison, Trans.) Northwestern University Press.

Derrida, J. (1978). Writing and difference. (A. Bass, Trans.) London: Routledge.

Derrida, J. (1982). Margins of philosophy. University of Chicago Press.

Derrida, J. (1983). The time of a thesis: punctuations. Derrida's defense essay, 34-50.

Derrida, J. (1991). Acts of literature. (D. Attridge, Ed.) Routledge.

Derrida, J. (1992). The other heading: Reflections on today's Europe. Indiana University Press.

Derrida, J. (1993). Structure, Sign, and Play in the Discourse of the Human Sciences. The Johns

Hopkins University.

Derrida, J. (1995). On the name. (T. Dutoit, Ed.) Stanford University Press.

Derrida, J. (1995). The gift of death. University of Chicago Press.

Derrida, J. (1997). DECONSTRUCTION IN A NUTSHELL: A CONVERSATION WITH JACQUES DERRIDA. Fordham University Press. 
Deconstruction of the Construction:

Derridean Study of Selected Shakespeare's Comedies

Derrida, J. (1998). Monolingualism of the Other: or, The Prosthesis of Origin (Cultural Memory in the

Present). (P. MENSAH, Trans.) Stanford University Press.

Derrida, J. (1998). The Politics of Friendship. The Journal of Philosophy, 85(11), 632-644.

Derrida, J. (2005). Rogues: Two essays on reason. Stanford University Press.

Derrida, J. (2006). Specters of Marx: The State of the Debt, The Work of Mourning \& the New International (P. Kamuf, Trans.) Routledge.

Derrida, J. (2010). On cosmopolitanism and forgiveness. Routledge.

Derrida, J. (2016). Of grammatology. (G. C. Spivak, Trans.) JHU Press.

Derrida, J. a. (2000). Of hospitality: Anne Dufourmantelle invites Jacques Derrida to respond. Stanford University Press.

Dutton, R., \& Howard, J. E. (2005). A Companion to Shakespeare's Works, Volume III: The Comedies. Wiley-Blackwell.

Evans, M. (2002). Deconstructing Shakespeare's Comedies. In J. Drakakis, Alternative Shakespeares. London: Routledge.

Ford, J. R. (2006). Twelfth Night: A Guide to the Play. Penn State Press.

Frug, G. (1984). The Ideology of Bureaucracy in American Law. 97 Harv. L. Rev. 1276.

Frye, N. (1964). Criticism, Visible and Invisible. College English, v26, n1. p3-12.

Hooti, N. (2013). William Shakespeare's Hamlet: a deconstructionist study. International Research Journal of Applied and Basic Sciences, 3903-3909.

Kitch, A. (2008, summer). Shylock's Sacred Nation. Shakespeare Quarterly, 131-155. doi: $10.2307 / 40210261$

Laroque, F. (2005). Shakespeare's Festive Comedies. In R. Dutton \& E. Howard, (Eds), A Companion to Shakespeare's Works: The Comedies. London: Blackwell.

Marciano, L. (2003, Fall). The Serious Comedy of Twelfth Night. Essays on Values in Literature, 56(1), pp. 3-19. doi: https://doi.org/10.5840/renascence20035611

Marcus, T. (2016). Spectres of Shakespeare: Ong Keng Sen's Search: Hamlet and the intercultural myth. A Journal of English Renaissance Studies. doi:10.1177/0184767816642986

Marrapodi, M. (2004). Shakespeare, Italy, and Intertextuality. Manchester University Press.

McQuillan, M. (2003). "Foreword - What is Called Literature." Genesis, Genealogies, Genres, \& Genius. New York: Columbia University Press.

Omrani, E., Royanian, S. \& Shabanirad, E. (2016). Class oppression, commodification, and consumerism in Dreiser's Sister Carrie. Khazar Journal of Humanities and Social Sciences, 19 (3), 39-59. DOI: 10.5782/2223-2621.2016.19.3.39

Peller, G. (1985). The Metaphysics of American Law. 73 Calif. L. Rev. 1151.

Philip, D. C. (2006). Stuffed with all honourable virtues": Much Ado About Nothing and The Book of the Courtier. Studies in Philology, 281-312. Retrieved from https://www.jstor.org/stable/4174852

Shakespeare, W. (1975). Twelfth night. (J. M. Lothian, \& T. W. Craik, Eds.) London: Methuen.

Shakespeare, W. (2009). Bloom's Modern Critical Views. Comedies. Infohouse Publishing.

Shakespeare, W., \& Percival, H. M. (1912). Merchant of Venice. Henry Frowde, Oxford University Press.

Shapiro, M. (1996). Gender in Play on the Shakespearean Stage: Boy Heroines and Female Pages. University of Michigan Press.

Slaingar, L. (1974). Shakespeare and the Traditions of Comedy. Cambridge University Press.

Unger, R. (1986). The Critical Legal Studies Movement. Cambridge: Harvard University Press. 
Whalley, J. \& Miller, L. (2016). Between Us: Audiences, Affect and the In-Between. London: Palgrave and McMillan.

Wolfreys, J. (2003). Critical keywords in literary and cultural theory. Palgrave Macmillan.

Wolfreys, J. (2005) (Ed). The J. Hillis Miller Reader. Stanford: Stanford University Press.

Woodbridge, L. (1989). Shakespeare: A Selective Bibliography of Modern Criticism. Locust Hill.

Wortham, S. M. (2010). The Derrida dictionary. Bloomsbury Publishing. 